photograph of an important Egyptian tomb-painting depicting Minoan ambassadors bringing rare vases of Cretan workmanship to the court of Queen Hatasu or Hatshepsu at Thebes.

In connection with the point raised anent the Minoan way, already described, at Knossos, that there was a great gap in history between the last (presumably non-Aryan) Minoans and the first (Aryan) Hellenes, we may note that Mr. R. S. Conway returns to the charge in defence of the "Aryanism" of the Minoans in another article on the Eteocretan inscriptions of classical times, which he considers to represent the speech of the Minoan Cretans. There is no proof of this whatever, and even if Mr. Conway were to succeed in proving the Indo-European character of this late "Eteocretan" language up to the hilt, this would not in the least shake our conviction that the old Minoans spoke a non-Indo-European tongue. The craniological and archæological evidence must be taken into consideration as well as the philological, which can apparently be twisted into meaning anything that the investigator wishes. The craniologist assigns the Minoans to the "Mediterranean", race, to which the ancient Egyptians also belonged; and the archæologist brings the Minoan and Egyptian cultures back almost to a common origin. Further, $\mathrm{Mr}$. Conway's idea goes counter to those of many of the philologists themselves, especially Kretschmer, whose view that the præ-Hellenic speech of Greece was non-Aryan agrees with the results of craniological and archæological research, and is generally accepted now.

This completes the list of articles dealing directly or indirectly with the Minoan or Mycenæan antiquities, the relics of the prehistoric culture of Greece,

Mr. Dawkins contributes an interesting philological article, entitled "Notes from Karpathos," describing the linguistic phenomena of that little known island, which he visited two years ago. The dialect seems to be more divergent from that of Crete than might have been expected. It presents all the peculiar dialectical phenomena of the Southern Ægean. Such pronunciations as "hyaloshorzho" ( $\chi \gamma a \lambda$ 入̌̌op̌o $)$ for $\mathrm{K} a \lambda o \chi \omega$ ino , which strike one so forcibly in Crete, are well represented. Aberrant grammatical forms are not uncommon. The old third plural in $-\sigma \iota(\nu)$ survives. Here we have a considerable difference from Cretan practice, which prefers third plural in- $\nu \epsilon$ :

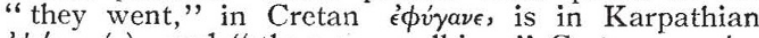

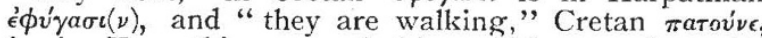
is in Karpathian $\pi a \tau o v \sigma \iota(\nu)$, which sounds quite "Attic." This is an interesting survival. Articles of this kind are of great use and value.

Mr. M. N. Tod and Mr. E. S. Forster add contributions to epigraphic scholarship, and the latter also describes Laconian topography and archæological sites. Mr. A. J. B. Wace has an article on Greek grotesque figures as charms against the evil eye. The modern Hellenes wear charms in the shape of little silver or coral figures of hunchbacks ( $g o b b i$ or gobbetti) for the same purpose.

Dr. Schäfer's German article on "Altägyptische Pflüge, Joche," is apparently published in the "Annual" on account of the ancient Egyptian basket figured on p. I40, which is of the same type as the Greek liknon, discussed by Miss Jane Harrison in her note on the "Mystica Vannus Iacchi," which follows. Otherwise one would have thought that its proper place would have been found in an Egyptological publication. The Berlin Museum has a large collection of ancient Egyptian agricultural implements, which are, however, of course all, with the exception of a fine plough and the basket aforesaid, of well known types equally well represented in other museums.

No. 1875 , voI. 72$]$

\section{SOUTH AFRICAN MEETING OF THE} BRITISH ASSOCIATION.

I ETTERS from local correspondents in South Africa have just brought us some notes upon the recent meeting of the British Association. During the progress of the meeting several cablegrams which appeared in the Times were summarised in these columns, so that many of the matters mentioned by our correspondents have already been recorded. Dr. J. D. F. Gilchrist has sent us an account of the part of the proceedings of the association at Cape Town, and the following particulars in so far as they are connected with Cape Town are from his communication. As, following our usual custom, we have arranged with officers of the sections for reports of the proceedings at sectional meetings, it is unnecessary now to give any account of these meetings.

Dr. Gilchrist states that as early as August 6 some of the British Association visitors began to arrive in Cape Town by the Tintagel Castle; eighteen .more arrived on August 8 by the Kildonan Castle, and fortythree by the Durham Castle on August 12 . The main body, however (eighty-six), including most of the official party, arrived by the Saxon on Tuesday, August 15 .

The voyage of the main party was favoured by excellent conditions of weather, and the usual routine of life and entertainments on board was diversified by lectures by members on appropriate subjects of interest, and in one or two cases by scientific work, such as the collecting of plankton and temperature observations of sea and air. A few advance copies of "Science in South Africa," a handbook prepared on the occasion of the visit, were on board, and afforded some insight into the scientific work and problems engaging the attention of South Africans.

On arrival at Cape Town Docks the passengers were transferred to the train waiting alongside, and about $10 \mathrm{a} . \mathrm{m}$. on August $\mathrm{I}_{5}$ arrived at the main station, where they were met by the mayor, the hospitality committee, and others. The council of the association met at $\mathbf{r} 2$ noon and the general meeting at 2 p.m., and the formal business was quickly got through.

The details of the somewhat extensive programme were in an advanced state of preparation, the general plan and coordination of the whole having been undertaken by a central organising committee for South Africa, the local details by the several reception committees at the seven local centres to be visited. These local committees were subdivided into entertainment, hospitality, excursions, and finance subcommittees.

Great assistance was rendered by Mr. Silva White, assistant secretary of the British Association, who arrived some weeks before the first meeting and took over the general direction of, and responsibility for, the arrangements. He arranged for the services of four assistant secretaries, who were instructed as to the details to be carried out on certain sections of the programme allotted to them, an arrangement which was fully justified by the subsequent results.

The formal business of the association commenced with the presidential address, which was delivered on the evening of August $x_{5}$ in the City Hall, which had just been completed in time for the meeting. The work of the various sections began the following day, and occupied the mornings from Wednesday, August I6, to Friday, August I8, half the sectional work being transacted at Cape Town and half at Johannesburg.

In the afternoon of August $x 6$ there was a large attendance at the Governor's garden party, and in the evening the Mayor met the visitors at a reception in the City Hall. 
A large number of papers were read on the mornings of the two following days. As a special feature of the papers and presidential addresses was their bearing on South African questions, exceptional interest was taken in the sectional proceedings.

The following excursions were made on August I 7 :-(I) botanical excursion to the Kloof Nek; (2) visit to Groote Schuur for lady members of the British Association by invitation of the Loyal Women's Guild of South Africa; (3) visit to the Central Electric Station of the Cape Town Corporation. In the evening a lecture was given in the City Hall before a crowded audience on "W. J. Burchell's Discoveries in South Africa," by Prof. E. B. Poulton, F.R.S.

The afternoon of August 18 was devoted to excursions; and a reception was held by Sir David and Lady Gill at the Royal Observatory. In the evening a lecture was given in the City Hall on "Some Surface Actions of Fluids" by Mr. C. V. Boys, F.R.S.

Saturday, August 19, was devoted entirely to the following excursions:--(I) geological excursion; (2) Wellington; (3) De Beers Explosive Works; (4) Houts Bay; (5) Groot Constantia and Tokai (6) Robben Island; (7) Stellenbosch; (8) Admiralty Works at Simons Town and Marine Station at St. James; (9) Table Mountain via. Saddle Face; (Io) Table Mountain viâ Wynberg; (I I) Table Mountain via Kasteel Poort.

Dr. W. Flint (librarian to the Houses of Parliament), who accompanied the association throughout its entire journey, has undertaken to send NATURE some account of the Natal, Johannesburg, and Rhodesian proceedings. The following notes are from a letter just received, with the promise of a further instalment by the next mail.

On the termination of the meeting in Cape Town the main body of the members of the association proceeded to Durban in the Union Castle steamers Saxon and Durham Castle. The former steamer left the docks on Friday evening, August 18 , and its passengers were debarred from taking part in the numerous Cape Town excursions which had been arranged for the Saturday. The Saxon passengers had, however, the advantage of brief visits to Port Elizabeth and East London, at each of which ports of call a few hours were spent, and hospitality was tendered by the mayor and citizens. The Durham Castle proceeded direct to Durban, and, making a record passage, arrived a little in advance of the mail steamer. A party of some thirty persons elected to proceed to Durban overland in one of the trains provided by the Cape Government, which was proceeding to Durban to meet the steamers. A special geological excursion through the Hex River Pass on to the Karroo captured a few enthusiasts, who, under the guidance of Mr. A. W. Rogers, of the Cape Geological Survey, spent a few days which proved to be of great interest. These members necessarily had to deprive themselves of the pleasure of the Natal section of the tour. The trip overland to Durban, which occupied four nights and three days, was unanimously voted a great success, and as several of the passengers are proceeding to England by Beira and the east coast, the opportunity of seeing the Karroo was much appreciated.

The two days spent in Durban and the neighbourhood were very fully occupied, the hospitable ideas of the mayor and his numerous helpers having provided a very attractive programme. Tuesday morning, August 22, was occupied in settling down and taking the bearings of the town, and early in the afternoon a public welcome was tendered by the mayor; Mr. Henwood, to which Prof. Darwin reNC, 1875 , vOL. 72 ] sponded. A garden party generously given by Sir Benjamin Greenacre, for which very elaborate preparations had been made, was partly spoiled by a heavy thunderstorm, but large numbers braved the downpour and were rewarded by seeing a few of the glories of the Berea.

Two lectures were given in Durban to very large audiences. Mr. Douglas W. Freshfield discoursed on "Mountains-the Highest Himalaya," and Prof. W. A. Herdman on "Marine Biology."

The second day in Durban was occupied chiefly with excursions. Perhaps the first place was taken by the entertainment provided by the Hon. Marshall Campbell at the Mount Edgecombe Sugar Estate. The contrast afforded by a Zulu war dance and a demonstration by Christian native girls was an object lesson which many were glad to have seen.

The excursion to Umkomaas was scarcely less enjoyed, the romantic subtropical scenery being a revelation to many of those who were privileged to be present. The botanists especially seemed to revel. in the opportunity, the wealth of Strelitzias in their native habitat being particularly attractive.

On Thursday morning, August 24, the whole party left in four trains, to be known henceforth as $\mathrm{A}, \mathrm{B}$, $\mathrm{C}$, and $\mathrm{D}$ trains, and arrived about mid-day in Maritzburg. The journey is one of the most attractive in South Africa, passing in its earlier stages through sugar, banana, and pine-apple plantations, and ascending rapidly to the Botha Hill heights, from which views of singular extensiveness and beauty are obtained. On reaching Maritzburg admirably complete arrangements were found to have been made, and members found themselves welcomed with great cordiality by Mr. A. W. Kershaw, the Mayor, and a host of willing citizens who had thrown themselves with great zeal into their task.

His Excellency Colonel Sir H. E. McCallum held a garden party at Government House which was a very successful function, and in the evening the Town Hall was thronged when His Excellency and the Mayor gave addresses of welcome. Colonel Bruce followed with a lecture on "Sleeping Sickness" which created great interest.

On the following day there were visits to the Government experimental farm and the Government laboratory, but it is to be feared that these were somewhat overshadowed by the Kafir dance and wedding which took place at Henley. The wedding was that of a young hereditary chief, and was preceded by the various dances and ceremonies customary on such an occasion. Never, probably, were so many photographs taken on a single day in Natal. The cameras were legion, and some of the photographers were not content with less than two or three dozen of pictures.

In the evening the young Natalian member of the official party, Mr. H. D. Ferrar, by special request, gave a lecture on "Antarctic Regions," he having been a member of the Discovery Antarctic Expedition.

Both in Durban and Maritzburg all members of the association had free use of the municipal trams, and nothing was left undone to ensure the comfort and enjoyment of the visitors, who in their turn were loud in their praises of the reception accorded.

\section{TWO REPORTS OF THE FRENCH GLACIER COMMISSION.}

AECORD of observations on snowfall and avalanches undertaken by the Forestry Department of Savoy during Igo4 on the south-west flank of Mont Blanc is contained in a paper entitled " Observations sur 1'Enneigement et sur les Chutes d'Avalanches," issued by the Commission française des Glaciers (Paris: Club Alpin français). The 